\title{
Functional categorization of de novo transcriptome assembly of Vanilla planifolia Jacks. potentially points to a translational regulation during early stages of infection by Fusarium oxysporum f. sp. vanillae
}

Marco Tulio Solano-De la Cruz ${ }^{1,2}$, Jacel Adame-García ${ }^{3}$, Josefat Gregorio-Jorge ${ }^{4}$, Verónica Jiménez-Jacinto 5 , Leticia Vega-Alvarado ${ }^{6}$, Lourdes Georgina Iglesias-Andreu', Esteban Elías Escobar-Hernández ${ }^{7}$ and Mauricio Luna-Rodríguez ${ }^{8^{*}}$

\begin{abstract}
Background: Upon exposure to unfavorable environmental conditions, plants need to respond quickly to maintain their homeostasis. For instance, physiological, biochemical and transcriptional changes occur during plant-pathogen interaction. In the case of Vanilla planifolia Jacks., a worldwide economically important crop, it is susceptible to Fusarium oxysporum f. sp. vanillae (Fov). This pathogen causes root and stem rot (RSR) in vanilla plants that lead to plant death. To investigate how vanilla plants, respond at the transcriptional level upon infection with Fov, here we employed the RNA-Seq approach to analyze the dynamics of whole-transcriptome changes during two-time frames of the infection.

Results: Analysis of global gene expression profiles upon infection by Fov indicated that the major transcriptional change occurred at 2 days post-inoculation (dpi), in comparison to $10 \mathrm{dpi}$. Briefly, the RNA-Seq analysis carried out in roots found that 3420 and 839 differentially expressed genes (DEGs) were detected at 2 and 10 dpi, respectively, as compared to the control. In the case of DEGs at $2 \mathrm{dpi}, 1563$ genes were found to be up-regulated, whereas 1857 genes were down-regulated. Moreover, functional categorization of DEGs at 2 dpi indicated that up-regulated genes are mainly associated to translation, whereas down-regulated genes are involved in cell wall remodeling. Among the translational-related transcripts, ribosomal proteins (RPs) were found increased their expression exclusively at $2 \mathrm{dpi}$.

Conclusions: The screening of transcriptional changes of $V$. planifolia Jacks upon infection by Fov provides insights into the plant molecular response, particularly at early stages of infection. The accumulation of translational-related transcripts at early stages of infection potentially points to a transcriptional reprogramming coupled with a translational regulation in vanilla plants upon infection by Fov. Altogether, the results presented here highlight potential molecular players that might be further studied to improve Fov-induced resistance in vanilla plants.
\end{abstract}

Keywords: Translational regulation, Biological defense, Transcriptional reprogramming, Biotic stress, Ribosomal proteins

\footnotetext{
* Correspondence: mluna@uv.mx

${ }^{8}$ Laboratorio de Genética e Interacciones Planta Microorganismos, Facultad

de Ciencias Agrícolas, Universidad Veracruzana. Circuito Gonzalo Aguirre

Beltrán s/n, Zona Universitaria, Xalapa, Veracruz, Mexico

Full list of author information is available at the end of the article
}

(c) The Author(s). 2019 Open Access This article is distributed under the terms of the Creative Commons Attribution 4.0 International License (http://creativecommons.org/licenses/by/4.0/), which permits unrestricted use, distribution, and reproduction in any medium, provided you give appropriate credit to the original author(s) and the source, provide a link to the Creative Commons license, and indicate if changes were made. The Creative Commons Public Domain Dedication waiver (http://creativecommons.org/publicdomain/zero/1.0/) applies to the data made available in this article, unless otherwise stated. 


\section{Background}

Throughout evolution, plants have developed multiple defense strategies to cope with pathogens. The first defense line consists of pre-existing physical and chemical barriers, which restrict their entry [1]. In addition to these constitutive barriers, plants have developed an immune response mechanism that is based on the detection of elicitor compounds derived from pathogens, known as Pathogen-Associated Molecular Patterns (PAMPs) [2]. Such defense response activated by the PAMPs or PAMP-Triggered Immunity (PTI), usually restricts the proliferation of the pathogen [3-7]. However, some pathogens have circumvented this response by developing effector proteins that interfere or suppress PTI [8-10]. In this sense, the so-called co-evolutionary 'arms race' between plants and pathogens has defined the establishment of the Effector-Triggered Immunity (ETI), a defense line that begins with the recognition of PAMPs by plant pattern recognition receptors (PRRs) [11]. The signals generated by PRRs are transduced through Mitogen-activated Protein Kinases (MAPKs), which in turn activate transcription factors for gene regulation that leads to a proper plant defense response [12]. Among the plant responses, the Hypersensitive Response (HR), the programmed cell death, the expression of proteins related to pathogenesis or the lignification of the cell wall are included [13-18].

Vanilla planifolia Jacks. is one of the most economically relevant orchids. It is produced extensively in several countries and is the main natural source of one of the most widely used flavoring agents in the world, vanillin $[19,20]$. Its cultivation has spread throughout the world, with Madagascar and Indonesia as the leaders of annual production (35.5 and 34.5\%, respectively), followed by China (13.7\%) and Papua New Guinea (4.1\%) [21-25]. Although Mexico is the center of domestication and diversification of this crop, vanillin production is positioned in the fifth place, contributing to only $4.0 \%$ of world production [20]. Importantly, vanilla plants are susceptible to parasites and pathogens. The most lethal pathogen that afflicts vanilla is Fov, a pathogenic form of the genus Fusarium that specifically infects this plant species [22, 25, 26]. This pathogen causes RSR, as well as the colonization of vascular tissues that finally leads to plant death. Several studies indicate that $V$. planifolia has a high susceptibility and incidence of Fov [25, 27, 28]. For instance, infection of vanilla plants by this pathogen is capable of destroying $65 \%$ of the plantation $[22,25,26]$. The lack of genetic variability of $V$. planifolia is another factor that worsens the scenario [26, 29, 30]. Thus, given the economic importance of $V$. planifolia, is mandatory to do an effort to elucidate the overall plant response upon infection by this pathogen, likewise, has been done in other crops [31-33]. Moreover, since inferences from mRNA expression data are valuable as it reflects changes with a biological meaning, we looked into the transcriptome of $V$. planifolia roots exposed to Fov, to figure out the responsive mechanisms at early (2 days after inoculation, 2dpi) and later (10 days after inoculation, $10 \mathrm{dpi}$ ) stages of infection. Gene expression profiles indicated that major transcriptional changes occur at $2 \mathrm{dpi}$. Accordingly, vanilla plants accumulate transcripts associated to several processes, but mostly translational regulation-related transcripts. Thus, this study provides the identification of molecular players in plant-pathogen interaction between $V$. planifolia and $F$. oxysporum f. sp. vanillae, particularly a transcriptional reprogramming coupled with a translational regulation. Our study is aimed to understand the response of vanilla plants, which could help to fight the most damaging disease of vanilla caused by Fov.

\section{Results}

\section{Assembly of the transcriptome of $V$. planifolia roots} exposed to Fov

The transcriptome of vanilla roots exposed to Fov was assessed with Illumina sequencing at 2 and $10 \mathrm{dpi}$. A total of $12 \mathrm{cDNA}$ libraries were paired-end sequenced using the NextSeq 500 system. Sequencing data of these libraries were obtained corresponding to three biological replicates (control and treatment), covering two frames of time along the infection process (Fig. 1). In brief, six libraries corresponding to control and treatment at $2 \mathrm{dpi}$, as well as six libraries at $10 \mathrm{dpi}$, produced more than 204 million reads (Fig. 1). Such data were submitted to the GEO platform of NCBI-GenBank (Accession number: GSE134155). To analyze and compare the dispersion of the treatments with respect to the control samples, PCA analyzes were carried out (Additional file 1: Figure S1; and Additional file 2: Figure S2). Additional file 1: Figure S1 corresponds to the treatment and control at $2 \mathrm{dpi}$, whereas Additional file 2: Figure S2 corresponds to the treatment and control at 10 dpi; respectively. Pre-processing of raw sequencing reads was carried out with FastQC, which indicated a good per base quality. The results of the quality analysis applied to the raw data, with FastQC software, are hosted under the following link: http://www.uusmb.unam.mx/reportes/1703 08/Project_MTulio.html (Additional file 3: Table S1). Filtering reads that correspond to the pathogen used at 2 and 10 dpi, discarded 5.33 and 39\%, respectively. On the other hand, even that control plants were not inoculated with the fungus, $5 \%$ (2 dpi) and $6.48 \%$ (10 dpi) of reads aligned to the genome of $F$. oxysporum $\mathrm{f}$. sp. lycopersici, excluding such reads for subsequent analyzes (Fig. 1). The de novo transcriptome assembly of vanilla resulted in about 45,000 transcripts (Additional file 4: Figure S3). The statistics of the transcriptome assembly carried out by TransRate v1.0.3 [34] can be found in (Additional file 5: Table S2) (Accession number: GSE134155). In addition, the results of processing 


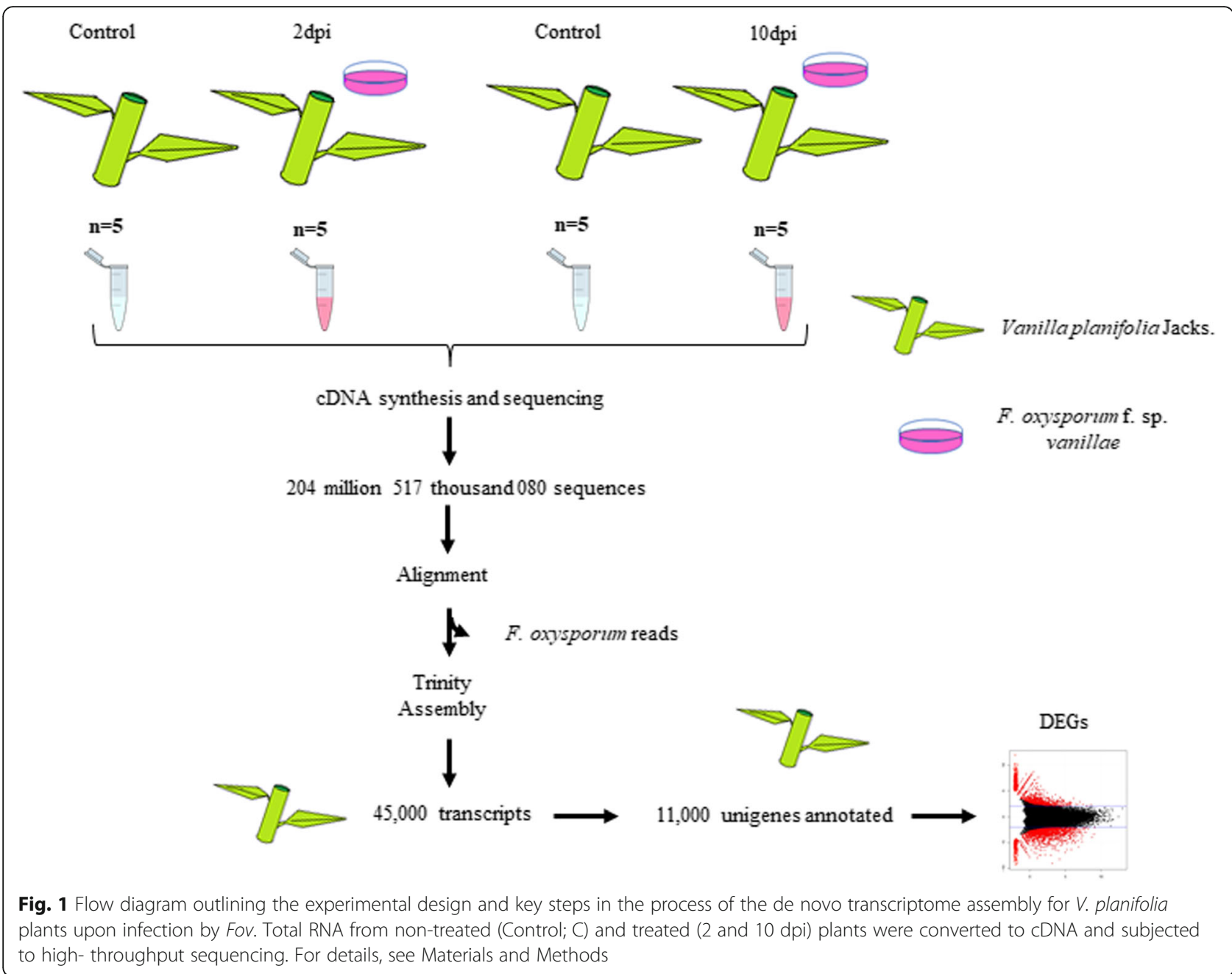

data, which involved sequencing statistics of raw data and filtered data, statistics of the sequence alignments vs. the de novo transcriptome assembly [35], as well as non-aligned sequences and records of sequences that were cleaned are presented in (Additional file 3: Table S1). The generated transcripts were mapped against the plant databases, using the BUSCO software, obtaining about $99 \%$ of complete orthologous. Additional file 1: Figure S1 shows the results of the annotation of the vanilla transcriptome with Blast2GO, finding about 11,000 unigenes out of the total 45,000 assembled transcripts (Additional file 4: Figure S3). Among the main functional categories of gene ontology obtained were plant development, plant growth, cell proliferation, signaling, response to stimuli and response to stress. Moreover, counting of reads on the assembled transcripts resulted in approximately $30 \%$ of transcripts that fulfilled the counts per million required for the subsequent identification of DEGs. Altogether, the assessment of the transcriptome of $V$. planifolia roots exposed to Fov revealed that several plant and cellular processes are impacted during the two frames of time evaluated.
Analysis of gene expression and functional categorization of DEGs at 2 and $10 \mathrm{dpi}$

For the identification of unigenes with changes in expression levels at 2 and $10 \mathrm{dpi}$, differential gene expression analysis was carried out using several approaches such as DESeq, DESeq2, NOISeq and EdgeR. For libraries corresponding to $2 \mathrm{dpi}, 2310,1702,4080$ and 3420 DEGs were obtained with DESeq, DESeq2, NOISeq and EdgeR, respectively (Fig. 2) (Additional file 6: Table S3). On the other hand, analysis of DEGs at 10 dpi revealed that $812,534,839$ and 881 DEGs were obtained with DESeq, DESeq2, NOISeq and EdgeR, respectively (Fig. 2) (Additional file 6: Table S3). As EdgeR is the most popular method and taking into account that this method included the vast majority of DEGs, EdgeR was selected for the subsequent analysis (Fig. 2). In that sense, two lists were obtained, one corresponding to the treatment at 2 dpi containing 3420 DEGs and the other corresponding to the treatment at $10 \mathrm{dpi}$ with 881 DEGs. In the case of DEGs at $2 \mathrm{dpi}, 1563$ genes were found to be up-regulated, whereas 1857 genes were down-regulated. 


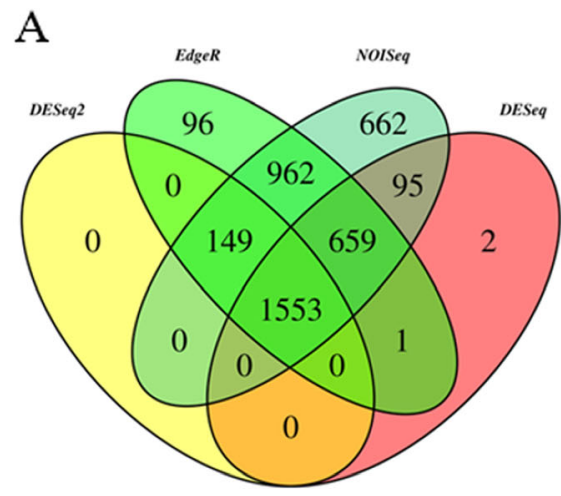

2 dpi

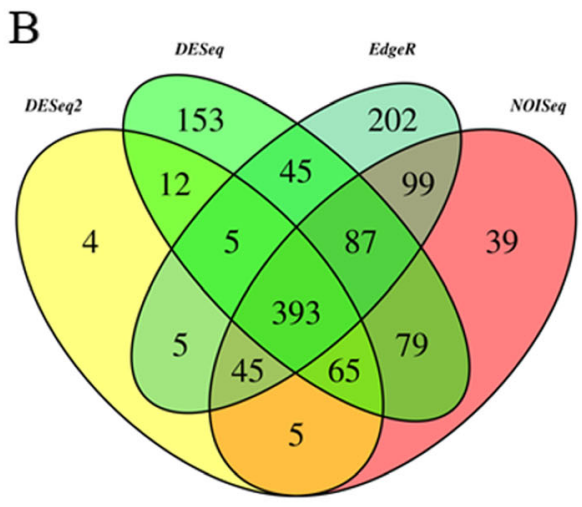

$10 \mathrm{dpi}$

Fig. 2 Venn diagrams showing the degree of overlap between DEGs obtained with different methods. a Number of DEGs obtained by DESeq, DESeq2, NOISeq and EdgeR for data set at 2 dpi. b Number of DEGs obtained for data set at 10 dpi with the same methods as shown in a. Results from each method are shown with different colors

On the other hand, classification of DEGs at $10 \mathrm{dpi}$ as up- and down-regulated genes, resulted in 250 and 631 genes, respectively. An overview of the transcriptional change at 2 and 10 dpi is shown in Fig. 3. At a glance, subsets of certain DEGs showed contrasting expression profiles if both treatments are compared (Fig. 3).

The lack of reference genome for $V$. planifolia forced to check orthology with available genomes for which annotation is complete. Accordingly, orthologs of Arabidopsis corresponding to DEGs at 2 and $10 \mathrm{dpi}$ were obtained, resulting in 603 and 278 orthologs, respectively (Additional file 7: Table S4). As a first approach to elucidate the putative functions of DEGs at 2 and $10 \mathrm{dpi}$, gene orthologs were submitted to MapMan [37]. Pathway analysis of DEGs with $P$-value cut-off of $\leq 0.05$ was carried out on Arabidopsis pathway genes. Accordingly, 603 (2 dpi) and 278 (10 dpi) DEGs were analyzed with MapMan, from which only 535 and 149 were categorized, respectively (Fig. 4). Visualization of the DEGs assigned to functional categories revealed that orthologs with differential expression at 2 dpi showed most enriched categories than that of 10 dpi (Fig. 4). Remarkably, most of data points contained within the functional categories at 2 dpi were up-regulated genes, whereas down-regulated genes were mostly associated to functional categories at $10 \mathrm{dpi}$ (Fig. 4). Among the most enriched categories, genes encoding products involved in regulation of transcription (27) and protein synthesis (29) were observed in both cases (2 and 10 dpi) (Fig. 4). However, the number of genes associated to those functional categories was contrasting. For instance, whereas only 20 data points were found within the category of protein for DEGs at $10 \mathrm{dpi}, 123$ were found in the case of data corresponding to 2 dpi (Fig. 4). Other enriched categories at 2 dpi were cell wall (10), lipid metabolism

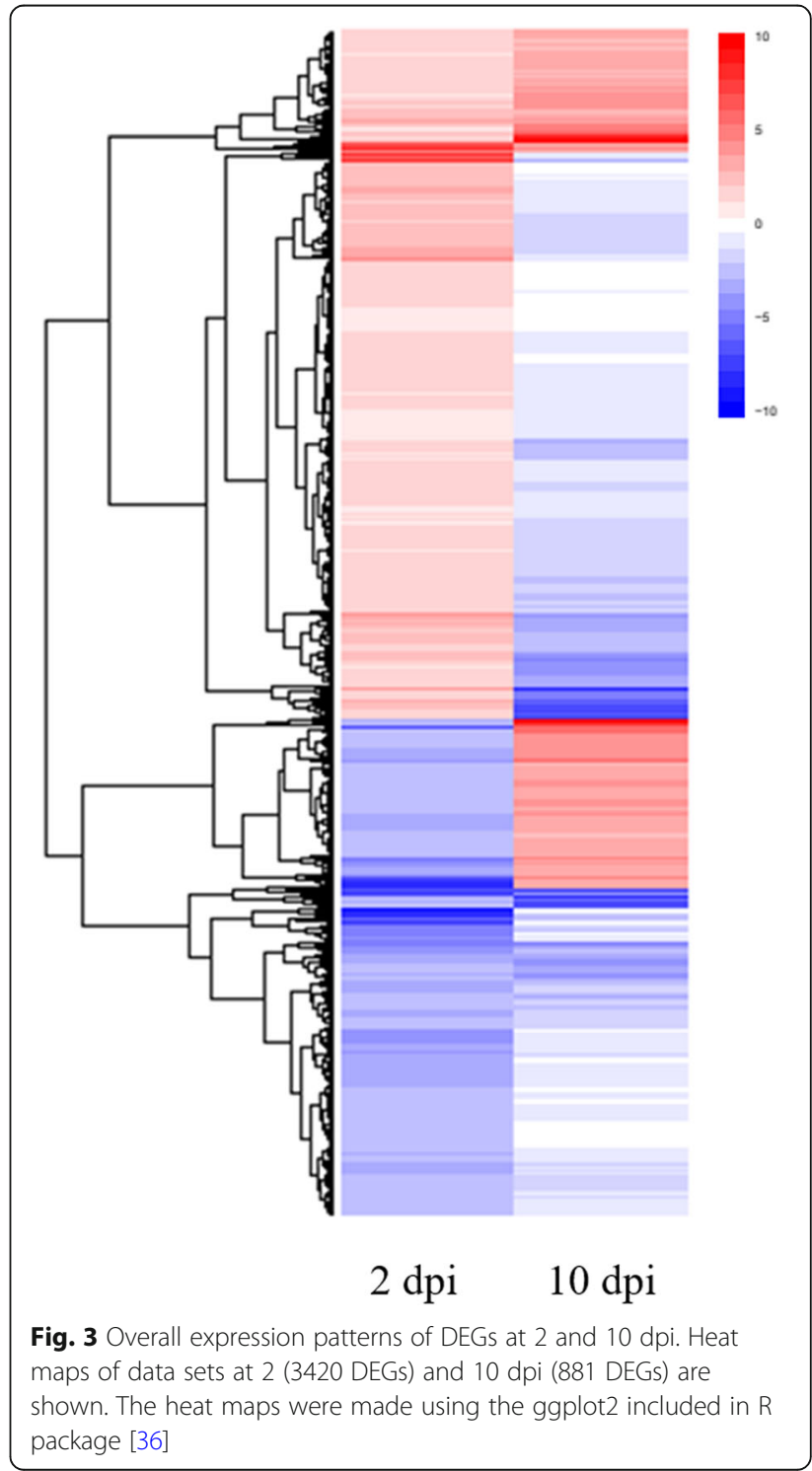




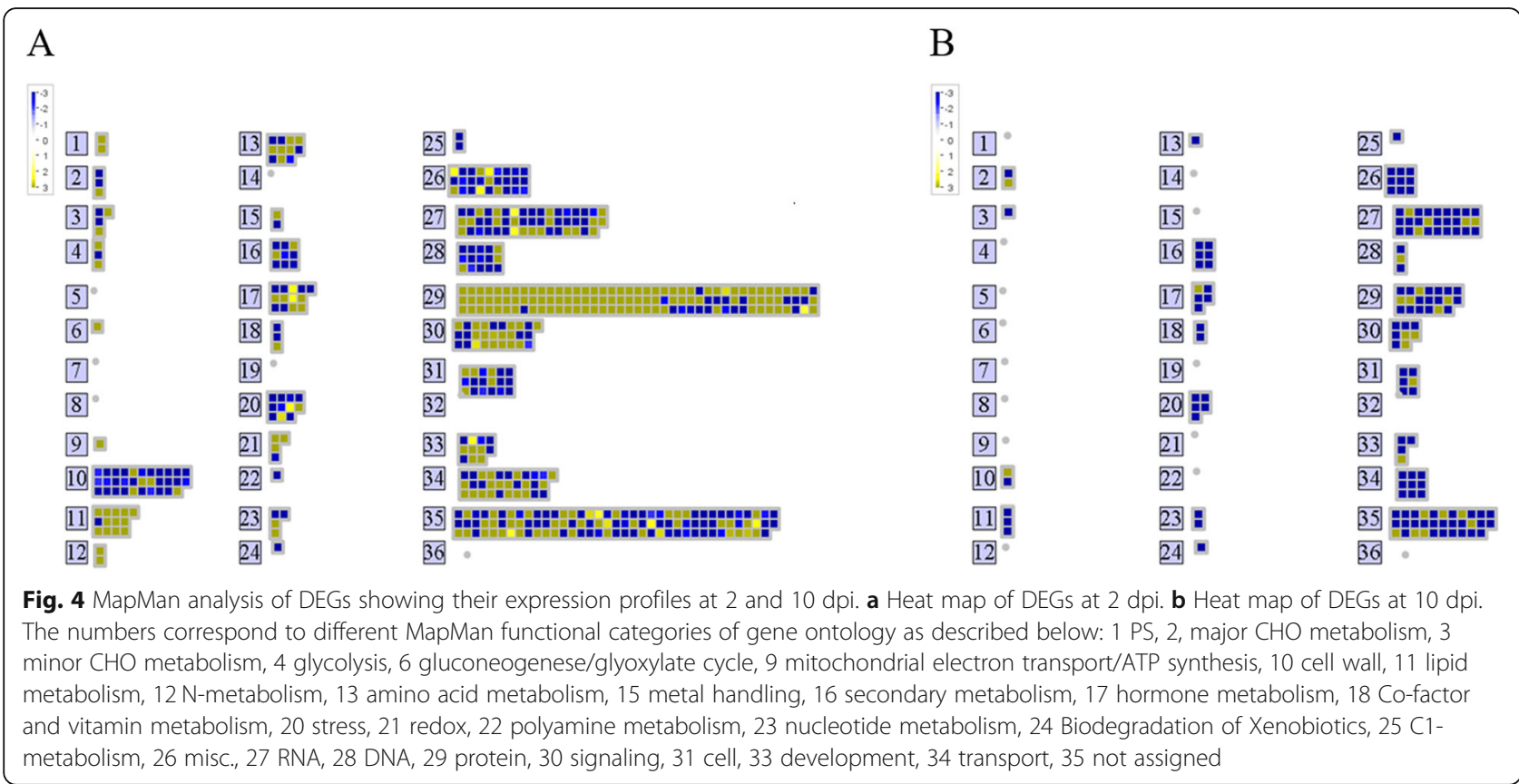

(11), amino acid metabolism (13), secondary metabolism (16) and hormone metabolism (17) (Fig. 4). Thus, the functional categorization of DEGs suggest that the major transcriptional change occurs at early stages of infection, namely at $2 \mathrm{dpi}$.

To further comprehend the functions of DEGs at 2 and $10 \mathrm{dpi}$, an analysis according to the enrichment of GO terms was carried out using the orthologs. Such analysis in the platform of agriGO resulted in the main functional categories associated to DEGs at 2 dpi (Table 1), but not for DEGs at 10 dpi. For upregulated genes at $2 \mathrm{dpi}, 18,4$ and 30 categories were significantly enriched, corresponding to biological process $(\mathrm{P})$, molecular function $(\mathrm{F})$ and cellular component $(\mathrm{C})$, respectively (Table 1$)$. The GO Term Enrichment Analysis was also performed with the PANTHER classification system software (v.14.0), to determine the categories of Gene Ontology significantly enriched in DEGs at $2 \mathrm{dpi}$, present in the up and down-regulated transcripts (Additional file 8: Table S5, and Additional file 9: Table S6 respectively). In the case of down-regulated genes, 9, 3 and 3 categories were found significantly enriches for $\mathrm{P}$, $\mathrm{F}$ and $\mathrm{C}$, respectively (Table 1 ). A schematic representation of biological processes shown in Table 1 allowed to appreciate that translation and cell wall modification were the main processes overrepresented in up- and down-regulated genes, respectively (Additional file 10: Figure S4). Taken together, the functional categorization of DEGs not only suggests that the major transcriptional change occurs at early stages of infection ( $2 \mathrm{dpi}$ ), but also indicates that up- regulated genes are mainly associated to translation, whereas down-regulated genes are involved in cell wall remodeling.

\section{Functional association networks of DEGs at 2 dpi}

Since the functional categorization suggested that DEGs coding for protein-related processes are the most contrasting categories when datasets of 2 and $10 \mathrm{dpi}$ are compared, further inspection was carried out for DEGs at $2 \mathrm{dpi}$. Since genes encode products that interact each other, a network was generated to look for relationships among DEGs at 2 dpi (Fig. 5). Briefly, out of 309 up-regulated genes at 2 dpi with an ortholog in the Arabidopsis genome, only 282 were recognized by String [38]. Accordingly, most of interactions observed in the network corresponded to experimental data (purple lines) (Fig. 5a). Particularly, a central network was formed, involving 98 genes (nodes), from which most of them ( 80 nodes) were related to translation (structural constituents of ribosome) (Fig. 5a). For example, genes encoding proteins such as Ribosomal protein S12/S23 (Rps12/ s23), Ribosomal protein l24B (Rpl24B), Ribosomal protein s6 (Rps6), Ribosomal protein s13 (Rps13), among others, formed the central network (Additional file 12: Table S7). In addition to genes involved in translation, genes associated to development were also found (Additional file 12: Table S7). Among this group, YODA (YDA), STEROL METHYLTRANSFERASE 1 (SMT1), EMBRYO DEFECTIVE 2386 (EMB2386), MATERNAL EFFECT EMBRYO ARREST 22 (MEE22), and others, were found (Additional file 12: Table S7).

On the other hand, for down-regulated genes at $2 \mathrm{dpi}, 256$ were recognized by String out of 294 submitted genes 
Table 1 Gene Ontology categories significantly enriched in DEGs at 2 dpi in the infection caused by Fusarium in vanilla

\begin{tabular}{|c|c|c|c|c|c|}
\hline DEGs & GO term & Ontology & Description & $p$-value & FDR \\
\hline \multirow[t]{44}{*}{ Up-Regulated } & GO:0006412 & $P$ & translation & $2.90 \mathrm{E}-41$ & $2.10 \mathrm{E}-38$ \\
\hline & GO:0034645 & $P$ & cellular macromolecule biosynthetic process & $6.50 \mathrm{E}-29$ & $1.90 \mathrm{E}-26$ \\
\hline & GO:0009058 & $P$ & biosynthetic process & $7.90 \mathrm{E}-29$ & $1.90 \mathrm{E}-26$ \\
\hline & GO:0009059 & $P$ & macromolecule biosynthetic process & $1.00 \mathrm{E}-28$ & $1.90 \mathrm{E}-26$ \\
\hline & GO:0044249 & P & cellular biosynthetic process & $2.80 \mathrm{E}-28$ & 4.00E-26 \\
\hline & GO:0019538 & $P$ & protein metabolic process & $1.10 \mathrm{E}-26$ & $1.30 \mathrm{E}-24$ \\
\hline & GO:0010467 & $P$ & gene expression & $1.80 \mathrm{E}-24$ & $1.90 \mathrm{E}-22$ \\
\hline & GO:0044267 & $P$ & cellular protein metabolic process & $2.70 \mathrm{E}-24$ & $2.40 \mathrm{E}-22$ \\
\hline & GO:0044238 & $P$ & primary metabolic process & $4.00 \mathrm{E}-24$ & $3.20 \mathrm{E}-22$ \\
\hline & GO:0043170 & $P$ & macromolecule metabolic process & $6.60 \mathrm{E}-21$ & $4.70 \mathrm{E}-19$ \\
\hline & GO:0008152 & $P$ & metabolic process & $1.40 \mathrm{E}-20$ & $9.10 \mathrm{E}-19$ \\
\hline & GO:0044260 & $P$ & cellular macromolecule metabolic process & 4.40E-19 & 2.60E-17 \\
\hline & GO:0044237 & P & cellular metabolic process & $3.40 \mathrm{E}-17$ & 1.90E-15 \\
\hline & GO:0009987 & $P$ & cellular process & $1.60 \mathrm{E}-16$ & $8.30 \mathrm{E}-15$ \\
\hline & GO:0042254 & $P$ & ribosome biogenesis & $2.70 \mathrm{E}-16$ & $1.30 \mathrm{E}-14$ \\
\hline & GO:0022613 & $P$ & ribonucleoprotein complex biogenesis & $6.60 \mathrm{E}-16$ & $3.00 \mathrm{E}-14$ \\
\hline & GO:0044085 & $P$ & cellular component biogenesis & $4.40 \mathrm{E}-11$ & 1.80E-09 \\
\hline & GO:0009791 & P & post-embryonic development & $3.90 \mathrm{E}-06$ & 0.00016 \\
\hline & GO:0003735 & $\mathrm{F}$ & structural constituent of ribosome & $4.20 \mathrm{E}-57$ & 1.40E-54 \\
\hline & GO:0005198 & $\mathrm{F}$ & structural molecule activity & $5.20 \mathrm{E}-50$ & $8.30 \mathrm{E}-48$ \\
\hline & GO:0008135 & $\mathrm{F}$ & translation factor activity, nucleic acid binding & $1.20 \mathrm{E}-07$ & 1.30E-05 \\
\hline & GO:0003746 & $\mathrm{F}$ & translation elongation factor activity & $6.10 \mathrm{E}-07$ & 4.90E-05 \\
\hline & GO:0022626 & C & cytosolic ribosome & $4.60 \mathrm{E}-65$ & $1.00 \mathrm{E}-62$ \\
\hline & GO:0044445 & C & cytosolic part & $1.00 \mathrm{E}-57$ & $1.10 \mathrm{E}-55$ \\
\hline & GO:0033279 & C & ribosomal subunit & $5.50 \mathrm{E}-56$ & 4.10E-54 \\
\hline & GO:0005840 & C & ribosome & $1.20 \mathrm{E}-55$ & $6.50 \mathrm{E}-54$ \\
\hline & GO:0030529 & C & ribonucleoprotein complex & $2.00 \mathrm{E}-48$ & $8.80 \mathrm{E}-47$ \\
\hline & GO:0043232 & C & intracellular non-membrane-bounded organelle & $3.70 \mathrm{E}-45$ & $1.20 \mathrm{E}-43$ \\
\hline & GO:0043228 & C & non-membrane-bounded organelle & $3.70 \mathrm{E}-45$ & $1.20 \mathrm{E}-43$ \\
\hline & GO:0005829 & C & cytosol & $3.90 \mathrm{E}-43$ & 1.10E-41 \\
\hline & GO:0022625 & C & cytosolic large ribosomal subunit & $3.20 \mathrm{E}-40$ & 7.70E-39 \\
\hline & GO:0015934 & C & large ribosomal subunit & $1.10 \mathrm{E}-35$ & 2.40E-34 \\
\hline & GO:0044422 & C & organelle part & $3.30 \mathrm{E}-30$ & $6.00 \mathrm{E}-29$ \\
\hline & GO:0044446 & C & intracellular organelle part & $3.20 \mathrm{E}-30$ & $6.00 \mathrm{E}-29$ \\
\hline & GO:0032991 & C & macromolecular complex & $7.00 \mathrm{E}-27$ & $1.20 \mathrm{E}-25$ \\
\hline & GO:0022627 & C & cytosolic small ribosomal subunit & $1.20 \mathrm{E}-22$ & $1.80 \mathrm{E}-21$ \\
\hline & GO:0015935 & C & small ribosomal subunit & $1.10 \mathrm{E}-20$ & 1.60E-19 \\
\hline & GO:0044444 & C & cytoplasmic part & $2.30 \mathrm{E}-19$ & $3.20 \mathrm{E}-18$ \\
\hline & GO:0005737 & C & cytoplasm & $2.80 \mathrm{E}-18$ & $3.70 \mathrm{E}-17$ \\
\hline & GO:0005730 & C & nucleolus & $2.70 \mathrm{E}-16$ & $3.20 \mathrm{E}-15$ \\
\hline & GO:0043229 & C & intracellular organelle & 4.40E-14 & $4.90 \mathrm{E}-13$ \\
\hline & GO:0005622 & C & intracellular & 4.40E-14 & $4.90 \mathrm{E}-13$ \\
\hline & GO:0043226 & C & organelle & 4.70E-14 & $4.90 \mathrm{E}-13$ \\
\hline & GO:0031981 & $C$ & nuclear lumen & $1.00 \mathrm{E}-13$ & 1.00E-12 \\
\hline
\end{tabular}


Table 1 Gene Ontology categories significantly enriched in DEGs at 2 dpi in the infection caused by Fusarium in vanilla (Continued)

\begin{tabular}{|c|c|c|c|c|c|}
\hline DEGs & GO term & Ontology & Description & $p$-value & FDR \\
\hline & GO:0044424 & C & intracellular part & $2.70 \mathrm{E}-13$ & $2.60 \mathrm{E}-12$ \\
\hline & GO:0043233 & C & organelle lumen & $2.20 \mathrm{E}-12$ & 1.90E-11 \\
\hline & GO:0070013 & C & intracellular organelle lumen & $2.20 \mathrm{E}-12$ & $1.90 \mathrm{E}-11$ \\
\hline & GO:0044428 & C & nuclear part & $2.50 \mathrm{E}-12$ & 2.10E-11 \\
\hline & GO:0031974 & C & membrane-enclosed lumen & $2.80 \mathrm{E}-12$ & 2.30E-11 \\
\hline & GO:0044464 & C & cell part & $1.80 \mathrm{E}-08$ & 1.30E-07 \\
\hline & GO:0005623 & C & cell & $1.80 \mathrm{E}-08$ & 1.30E-07 \\
\hline & GO:0016020 & C & membrane & 7.70E-07 & $5.60 \mathrm{E}-06$ \\
\hline \multirow[t]{15}{*}{ Down-Regulated } & GO:0042545 & $P$ & cell wall modification & $2.20 \mathrm{E}-06$ & 0.00088 \\
\hline & GO:0009664 & P & plant-type cell wall organization & $1.40 \mathrm{E}-06$ & 0.00088 \\
\hline & GO:0044262 & $P$ & cellular carbohydrate metabolic process & 4.70E-06 & 0.001 \\
\hline & GO:0005975 & P & carbohydrate metabolic process & $5.00 \mathrm{E}-06$ & 0.001 \\
\hline & GO:0005976 & P & polysaccharide metabolic process & 9.60E-06 & 0.0016 \\
\hline & GO:0006260 & P & DNA replication & $1.60 \mathrm{E}-05$ & 0.0021 \\
\hline & GO:0009827 & P & plant-type cell wall modification & 2.70E-05 & 0.0032 \\
\hline & GO:0060918 & $P$ & auxin transport & $5.70 \mathrm{E}-05$ & 0.0055 \\
\hline & GO:0009914 & $P$ & hormone transport & $6.20 \mathrm{E}-05$ & 0.0055 \\
\hline & GO:0003824 & $\mathrm{F}$ & catalytic activity & $1.30 \mathrm{E}-06$ & 0.00031 \\
\hline & GO:0016757 & $\mathrm{F}$ & transferase activity, transferring glycosyl groups & 7.00E-05 & 0.0075 \\
\hline & GO:0016758 & $\mathrm{F}$ & transferase activity, transferring hexosyl groups & $9.50 \mathrm{E}-05$ & 0.0075 \\
\hline & GO:0030312 & C & external encapsulating structure & $6.70 \mathrm{E}-07$ & 4.70E-05 \\
\hline & GO:0005618 & C & cell wall & $5.90 \mathrm{E}-07$ & 4.70E-05 \\
\hline & GO:0031225 & C & anchored to membrane & $9.00 \mathrm{E}-05$ & 0.0042 \\
\hline
\end{tabular}

In the table the Gene Ontology (GO) terms that are significantly ( $q \leq 0.05$ ) overrepresented using AgriGO V2 are observed. $\mathrm{P}$ corresponds to Biological Process, $\mathrm{C}$ corresponds to Cellular Component, and F corresponds to Molecular Function

(Fig. 5b). Also, a central network (49 nodes) was obtained with genes involved mainly in cell cycle, DNA replication and cell wall organization (Fig. 5b) (Additional file 12: Table S7). In this case, genes encoding proteins such as Cyclin A1;1 (CycA1;1), Cyclin-dependent kinase B2 (CdkB2), Minichromosome maintenance 3 (Mcm3), Origin recognition complex subunit 3 (Orc3), Cellulose synthase-like protein D5 (Csld5), Cellulose synthase A catalytic subunit 8 (CesA8), Cellulose synthase A catalytic subunit 7 (CesA7), among others, clearly formed a central network (Fig. 5b) (Additional file 12: Table S7). Notably, these networks were exclusively for DEGs at $2 \mathrm{dpi}$, since DEGs corresponding to $10 \mathrm{dpi}$ did not show a clear interaction (Additional file 11: Figure S5). In resume, the generation and visualization of relationships among DEGs at 2 dpi show significantly more interactions than expected. In the case of up-regulated genes, they are mainly associated to ribosome biogenesis and translation as well as in development, whereas down-regulated genes are involved in cell cycle, DNA replication and cell wall organization.

\section{Differential gene expression of ribosome-related proteins} at 2 dpi

The finding that mainly proteins involved in ribosome biogenesis and translation (structural constituents of ribosome) were the most significant DEGs at $2 \mathrm{dpi}$, encouraged to focus on these genes. As observed in Fig. 6, proteins related to ribosome biogenesis and translation were significantly up-regulated in $2 \mathrm{dpi}$ compared to $10 \mathrm{dpi}, 72$ of which were exclusively expressed in the treatment at $2 \mathrm{dpi}$. These exclusive genes corresponded to ribosomal proteins, for which a significant increase in their expression pattern was observed only at 2 dpi (Fig. 6). As mentioned before, ribosomal proteins such as Ribosomal protein s12/s23 (Rps12/S23), Ribosomal protein 124B (Rpl24B), Ribosomal protein s6 (Rps6), Ribosomal protein s13 (Rps13), among others, were found up-regulated at $2 \mathrm{dpi}$. In summary, ribosomal-related proteins are found up-regulated at $2 \mathrm{dpi}$, suggesting that translation is impacted upon infection by Fov.

\section{Discussion}

As supported by several studies around the world, Fov is the principal species that causes RSR in vanilla plants [25, 


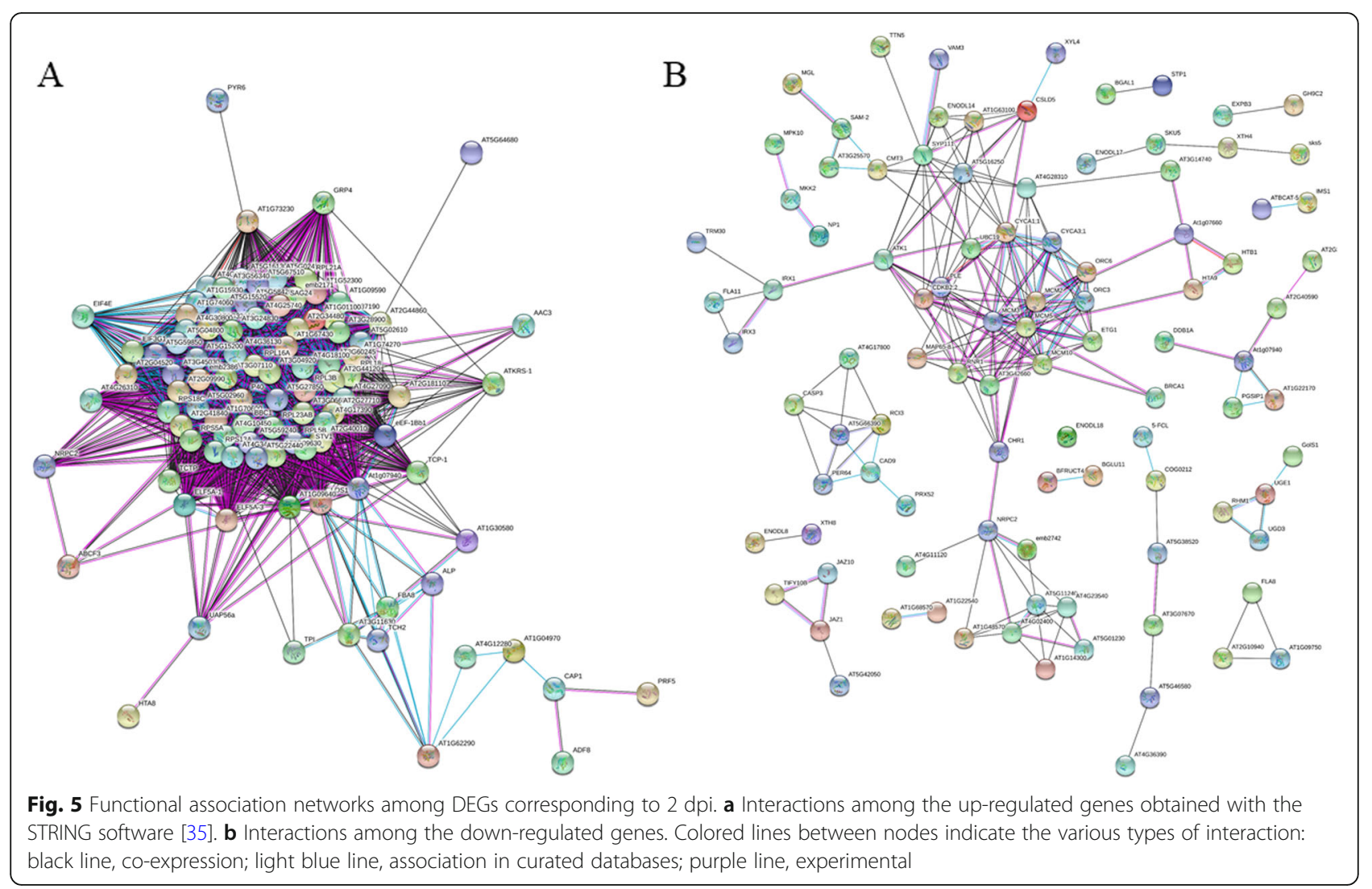

39, 40]. Although the generation and use of resistant varieties are the best mean to restrict Fov, scarce information about the plant-pathogen interaction, as well as limited genetic resources, have impeded to eradicate or limit the devastation that cause Fov in vanilla production. Under such scenario, the understanding of mechanistic responses of vanilla plants upon infection by Fov is scarce and necessary. Therefore, the primary goal of this work was to elucidate the early and late mechanistic responses of vanilla plants induced by Fov through investigating whole transcriptional changes in root tissues (Fig. 1). The RNA-Seq technique was employed to detect the DEGs during two frame times of infection by this root-infecting fungal pathogen, namely at early ( $2 \mathrm{dpi})$ and late $(10 \mathrm{dpi})$ stages. The RNA-Seq analysis carried out in roots revealed that 4480 and 881 genes were differentially modulated by Fov at 2 and $10 \mathrm{dpi}$, respectively, as compared to the control (Fig. 2). This result indicated that the major transcriptional change occurs at early stages of infection, encouraging further analysis for these DEGs (Fig. 3). After functional classification of DEGs at 2 and $10 \mathrm{dpi}$, it was further confirmed that only DEGs at 2 dpi contained enriched functional categories (Fig. 4). For instance, enrichment analyses revealed the involvement of DEGs at 2 dpi to ribosome biogenesis and translation for up-regulated genes, whereas down-regulated genes were mainly associated to cell wall biogenesis (Table 1).
Most biological processes, from cell differentiation to organ development, as well as the adaptation to the environment, relies on transcriptional adjustments. Even that gene expression regulation is solidly established, it is clear that regulation beyond this level also plays a pivotal role in modulating key biological processes. Among the enriched functional categories for DEGs at $2 \mathrm{dpi}$, translation was the most prominent among up-regulated genes (Table 1) (Additional file 10: Figure S4), suggesting that this biological process is significantly impacted upon infection by Fov. Moreover, the formation a single network involving all these RPs supports a putative function in the early stages of infection by Fov (Fig. 5a). On the other hand, the finding that down-regulated genes are mostly involved in cell wall modifications (Table 1), is in agreement with the known susceptibility of $V$. planifolia plants to Fov. In this regard, since the plant cell wall acts as an important barrier against pathogen penetration by activating cell wall strengthening-related genes [41], the down-regulation of these genes reflects the facilitation of pathogen entry and then the negative impact on processes such as cell division and DNA replication of plant cells (Fig. 5b).

Being the basic infrastructure for protein translation, ribosomal proteins (RPs) have been known primarily for their housekeeping functions [42]. However, in the recent years, emerging functions of RPs have been 


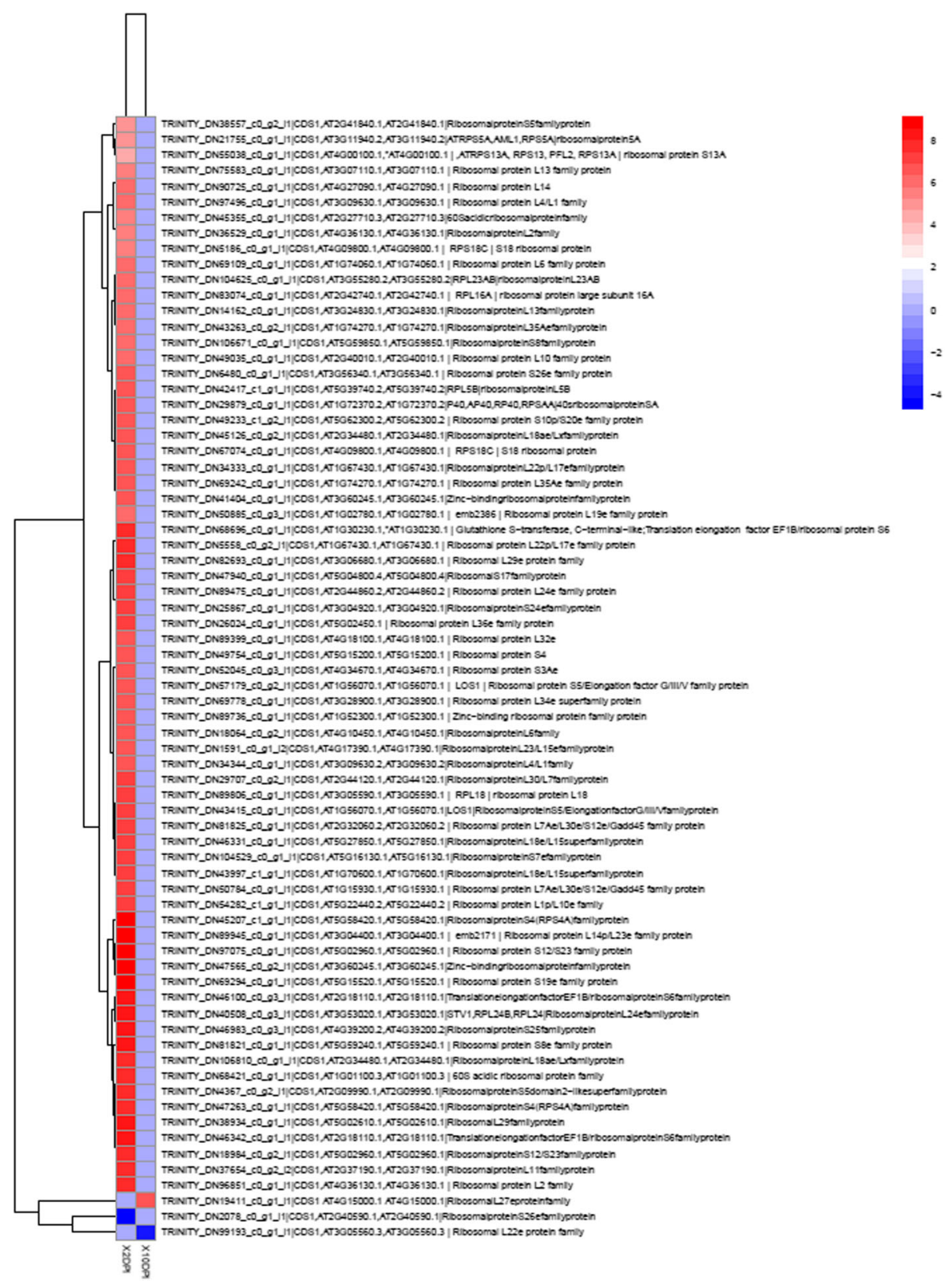

Fig. 6 Heat map of ribosomal proteins comparing datasets of 2 and 10 dpi. The heat maps were made using the ggplot2 included in R package [36]

described, including regulation of gene expression through translational mechanisms [43, 44]. One hint for this is, for example, that even there are at least 230 genes encoding RPs in the Arabidopsis genome, a single member of each family of RPs has been found as part of the subunits of ribosomes, suggesting that expression of the additional RPs are subjected to different cues, including environmental conditions $[45,46]$. Among the upregulated RPs found in this work, RPL13 has been related to the tolerance of potato to Verticullum dahliae [47]. Similarly, RPL10, RPS12/S23, and PRPL19e [48, 49], as well as the expression of RPS6, RPL19, RPL7, and
RPS2 [50], have been associated to plant response against bacteria and virus; respectively. Also, RPS10 and $R P S 10 p / S 20$ e have been found to be up-regulated by Phytophthora sojae in Glycine max [51]. Finally, RPL12 and RPL19 also have been shown to participate in the resistance against $P$. syringae in Nicotiana benthamiana and $A$. thaliana, respectively $[49,52]$. On the other hand, abiotic stress has also been found to induce transcription of RPs. For example, transcript levels of RPS15a (and its variants $\mathrm{A}, \mathrm{C}, \mathrm{D}$ and F) increased significantly in response to heat stress in Arabidopsis [53]. This was also the case for RPS14, RPL13, and RPL30 in 
Arabidopsis, in which their expression levels augment under the treatment with benzylaminopurine [54]. In addition, RPL10 and RPL10C were induced when Arabidopsis plants were treated with UV, like those results obtained in maize plants $[55,56]$. Finally, regarding low temperature conditions, increase of RPS6, RPS13 and RPL37 have been observed in Glycine max and Brassica napus $[57,58]$. Besides the association of these RPs to biotic or abiotic stresses, functional characterization of them has allowed to elucidate their role in plants. In that sense, mutation of RPL10 causes lethality of the female gametophyte in Arabidopsis [59]. Also, the mutation of RPS13A results in a reduction of cell division, retardation of flowering, and delayed growth of shoots and leaves [60]. Similar phenotypes of growth retardation and fertility reduction have been reported in the RPL23aA mutant [61]. In summary, until now, the central role of RPs in development as their global participation in response to abiotic stress in iron and phosphate deficit conditions has been assessed. Here, we report for the first time the RPs global participation in response to biotic stress in a translational manner.

Since translation of proteins is energetically a demanding process, stress can cause a global drop of protein synthesis in plants. However, a translational regulation mechanism leading to the translation of certain transcripts to produce specific RPs may be the key to the survival of plants under stressful conditions [42]. Only in recent years this kind of regulation beyond the transcriptional level has received special interest due to its implications in key biological processes, particularly those related to biotic and abiotic stress responses [43, 44, 62]. Thus, the up-regulation of several RPs during early stages of infection by Fov in vanilla plants represent a whole response of translational regulation (Fig. 7), as known about of regulation of translational factors and their associated proteins with translational regulation [62]. In the transcriptional profile of vanilla plants at 2 dpi, induction of RPL24B, RPS18, RPS5 and RPL27A were found. Since $R P L 24 B$ of Arabidopsis is related to the translation regulation of some auxin signaling genes that contains uORFs [63, 64], the up-regulation of this $\mathrm{RP}$ in vanilla plants could suggest the presence of a similar mechanism. Supporting this hypothesis, mutants of $R P L 24 B$, as well as RPS18A, RPS5B, RPS13B and $R P L 27 A$, known as "pointed first leaf" mutants, show defective phenotypes related to development, such as the reduction of the growth of shoots and roots [60, 65-67]. This suggests that, these proteins carry out specific functions during plant development, likely by translating specific transcripts. Accordingly, RPS6, which is responsive to biotic and abiotic stresses, is also a regulator of translation [68]. Specifically, phosphorylation of RPS6 through the TOR signaling pathway lead to the selective

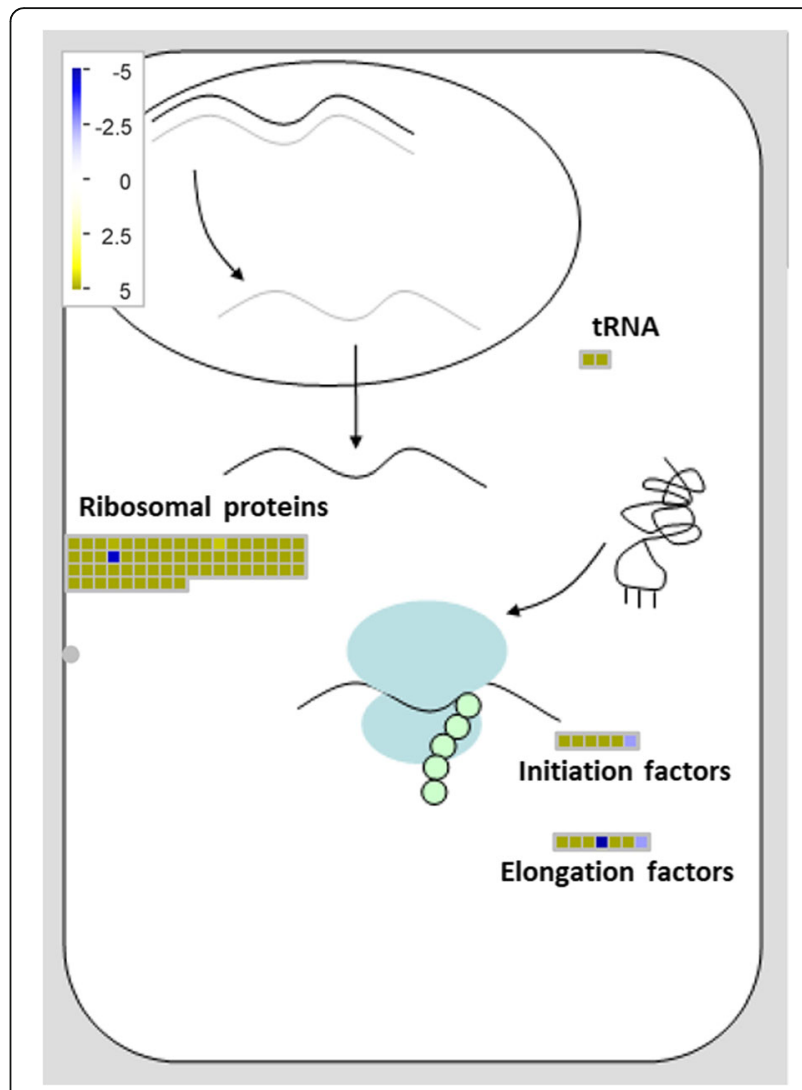

Fig. 7 Overview of MapMan RNA-protein synthesis at 2 dpi. Transcript levels of translation-related genes (RPs, tRNAs, initiation factors and elongation factors) are shown. Upon invasion by Fov, induction of RPs leads to changes in ribosome composition, driving to selective translation of certain transcripts

translation of mRNAs [42, 62]. Besides RPS6 phosphorylation, phosphorylation of eIF2 $\alpha$ by the Gen2-Gen1 complex reduces global protein synthesis, which has implications for growth and development [69-73]. Since GCN1, GCN2 and EIF2 $\alpha$ were exclusively found in DEGs at 2 dpi and its expression resulted to be high (near to $12 \log 2$ fold change), this suggest, same as in abiotic and biotic stress [74], that the general translation can be decreased, accompanied by selective translation through changes of ribosome composition as the response to pathogen infection.

Under such scenario, upon infection by Fov, root cells of vanilla plants likely change the expression of RPs, resulting in alterations of ribosomes composition, as reported against abiotic stress [75] and, therefore, in modulation of translation for certain transcripts as a response of fungal invasion (Fig. 7). This is particularly relevant since this is the first time that RPs are associated to Fov-derived response in vanilla plants. Moreover, it has been indicated that the typical chromosomal number of $V$. planifolia is $2 n=32$ and more recently, cytogenetic studies conducted in the Mansa morphotype, reported an intra-individual variation in the 
number of chromosomes in the apical cells of the root, which may vary from $2 n=20$ to $2 n=32$ or more. Likewise, the existence of a "progressively partial endoreplication" in $V$. planifolia has been reported, however, this process does not occur in all tissues and some studies have reported that less than half of the genome of $V$. planifolia is being replicating effectively in each cycle. However, we consider that the methodology used in this study minimizes the effect of this phenomenon, so we propose the role of the translational regulation in the early plant response in the interaction with pathogen [76].

\section{Conclusions}

The screening of transcriptional changes of $V$. planifolia upon infection by $F$. oxysporum $\mathrm{f}$. sp. vanillae shows that the major change occurs at early stages of infection, according to the analysis of DEGs at 2 dpi that shows, among other biological processes, the transcription of RPs increases specifically at this moment. Moreover, given the changes of these RPs are involved in plant developmental programs, as well as in response to biotic and abiotic stress conditions, their differential expression point to a biological role during infection. Therefore, is proposed that in response to Fov infection, root cells of vanilla plants activate a transcriptional reprogramming coupled with a translational regulation. The results presented here highlight key processes and potential molecular players that might be further studied to develop vanilla breeding programs, help to fight the most damaging disease of this crop.

\section{Methods}

\section{Plant material}

From plants of $V$. planifolia Jacks. (Mansa morphotype) growing on a farm located in the Totonacapan region (Veracruz, Mexico), samples were collected and propagated under greenhouse conditions. Vigorous and pathogen-free plants were used in the present study at the developmental age of 12 weeks for infectivity assays. Such plants exhibited leaf morphology characteristic of $V$. planifolia. Sixty plants were distributed in twelve groups of five each one, for an experimental design intended for four treatments (two times conditions and two control) and three biological replicates by treatment (Fig. 1). The time conditions were 2 dpi (2 days postinoculate) and $10 \mathrm{dpi}$ (10 days post-inoculate) and the controls were plants non-treated with Fov.

\section{Infectivity assays}

The in vitro fungal infection of $V$. planifolia plants was carried out with the JAGH3 strain of Fov. This strain of Fov was isolated from $V$. planifolia (Mansa morphotype) with evident RSR [77], its pathogenic capacity was proven, so it has been used for further studies [25, 40,
78]. Briefly, cuttings of $V$. planifolia were subjected to darkness for ten days. The absence of light exposition allowed the generation of new roots. A mechanical incision was made in each root under aseptic conditions. Then, roots were exposed to an aqueous solution of spores with a concentration of $1 \times 10^{6} \mathrm{CFU}$ of Fov (JAGH3 strain). The inoculation was carried out directly on the substrate where cuttings were established. Cuttings belonging to the control group were treated similarly, exposing them to an aqueous solution free of spores. For a single biological experiment, control and treatment experiments consisted of 30 plants of the same age, established on substrate and maintained under greenhouse conditions with a 12-h photoperiod (shaded). Two biological experiments were carried out covering two frames of time of Fov infection, namely 2 and 10 days post-inoculation (dpi) (Fig. 1). For each of the treatments and their respective controls, five tissue samples were collected in each case, pooled and processed immediately for RNA extraction. In total, twelve pools were obtained, covering two biological experiments for each treatment time ( 2 and $10 \mathrm{dpi})$.

The pathogenicity of the JAGH3 strain on vanilla plants was evaluated following the protocol specified by Koyyappurath et al., (2015) [79]; which is based on the observation and recording of infection symptoms, on the alternate days after inoculation. According to the above, the symptoms were observed and recorded on alternate days in aerial parts, which include aerial roots, in addition to the stem and leaves; The observation period was from day 1 to day 9 , after inoculation. The presence of the characteristic symptoms of the infection was monitored using a rating scale of $0-4$ as follows: $0=$ no symptoms; 1 = the leaves lost their brightness; $2=$ local browning visible on the stem; $3=$ lodging of plants, brown areas and mycelium visible in the aerial parts; and $4=$ totally rotten or dead plant.

\section{Total RNA extraction}

For the total RNA extraction from the roots of vanilla plants, a protocol was standardized based on a previous report [80]. Briefly, $200 \mathrm{mg}$ of root tissue were homogenized with the Trizol reagent and then treated with Phenol:Chloroform:Isoamyl Alcohol (25:24:1), followed by vortexing and centrifugation. The upper aqueous phase was transferred into silica columns included in the SV Total RNA Isolation System extraction kit from Promega. The integrity of the obtained RNA was determined by electrophoresis in $2 \%$ agarose gel, stained with ethidium bromide (EtBr $0.5 \mu \mathrm{g} \mathrm{ml}^{-1}$ ) under denaturing conditions. The concentration of total RNA samples was verified using a NanoDrop spectrophotometer, as well as its RNA Integrity Number (RIN) values were obtained with an Agilent 2100 Bioanalyzer system (Agilent 
Technologies). RNA samples with RIN values $>6$ were used for cDNA synthesis and subsequent sequencing.

\section{Generation and sequencing of CDNA libraries}

The generation and sequencing of the cDNA libraries was carried out in the University Unit of Massive Sequencing and Bioinformatics of the Institute of Biotechnology of the National Autonomous University of Mexico (UUSMB IBT-UNAM). In total, the construction of 12 cDNA libraries was carried out. Afterwards, the sequencing of the cDNA libraries was performed using the Nextseq 500 illumina platform, generating paired-end reads of $76 \mathrm{bp}$. In total, 204 million 517 thousand 080 reads were obtained.

\section{De novo transcriptome assembly and annotation}

Quality of reads obtained from the high-throughput sequencing was carried out using the FastQC software (https://www.bioinformatics.babraham.ac.uk/projects/ fastqc/). Reads above $32 \mathrm{nt}$, without the presence of adapters were considered for further analysis. First, to filter and discard reads corresponding to the plant pathogen used in the infectivity assays, alignment of reads was performed with the Smalt software (version 0.7.6) using the reference genome of $F$. oxysporum $\mathrm{f}$. sp. lycopersici strain Fol4287. Then, de novo transcriptome assembly corresponding to $V$. planifolia reads was made using the Trinity software (version 2.4). For assessing the quality of the obtained transcriptome assembly, metrics like total number of contigs, longest contig length, mean and median contig length, and N50 were calculated using TransRate, followed by an analysis with BUSCO to explore completeness according to conserved ortholog content. The analysis with the BUSCO software was carried out using the Liliopsida odb10* database, following the software default parameters [81]. Subsequently, the annotation of the transcriptions was made with the Trinotate software. The search for the open reading frames in the transcriptions was made with the TransDecoder software. Transcripts and amino acid sequences were aligned against the UniProt database using Blastn and Blastx. Moreover, the presence of PFAM domains in the protein sequences predicted from the transcripts was tested with the HMMER software. Finally, the annotation of the transcripts was done using Blast2go [36], as well as the databases of Gene Ontology (GO), KEGG, COG.

\section{Differential expression analysis and functional categorization}

For assessing differentially expressed genes (DEGs) of the assembled transcripts, a method based on mapping the reads against the assembled transcriptome was done. Such mapping of reads was done with Bowtie2, as part of the Trinity pipeline, followed by an analysis with RSEM. The results obtained by RSEM were submitted to IDEAMEX [82], a website intended for differential expression analysis using several approaches. Specifically, IDEAMEX analysis is based on DESeq [83], DESeq2 [84], NOISeq [85] and EdgeR [86] methods. For selection of DEGs, the following parameters were used: padj $<=0.04, \mathrm{FDR}<=0.04$ and prob. $>=0.96$, and a $\operatorname{logFC}>=$ 2. Heatmaps for DEGs were done in $\mathrm{R}$ using the ggplot2 package [87]. From the functional annotation of the assembled transcripts obtained by Blast2GO, visualization of the transcriptome regarding expression patterns was performed with Mapman V2 software [37]. For functional categorization, DEGs were submitted to the agriGO v2.0 software [88], selecting the singular enrichment analysis (SEA). The enrichment analysis was carried out according to the following parameters in the AgriGo v2.0 Software, Statistical test method Fisher; Multi test adjustment method: Yekutieli (FDR under dependency); and 0.05 of significance level. The enrichment analysis was also carried out with PANTHER classification system software (v.14.0). under the following specifications, statistical test method Fisher; Multi test adjustment method: Bonferroni; and 0.05 of significance level. Finally, gene networks among DEGs were obtained with the STRING software [38].

\section{Supplementary information}

Supplementary information accompanies this paper at https://doi.org/10. 1186/s12864-019-6229-5.

Additional file 1: Figure S1. PCA graph of 2 dpi treatment and control treatment. The graph analyzes the spatial dispersion between treatment and control and their respective replicas.

Additional file 2: Figure S2. PCA graph of 10 dpi treatment and control treatment. The graph analyzes the spatial dispersion between treatment and control and their respective replicas.

Additional file 3: Table S1. Statistics of sequencing and filtering of raw data.

Additional file 4: Figure S3. Annotation all unigenes derived from the de novo transcriptome assembly of $V$. planifolia upon infection by Fov. Annotation was based on Gene Ontology terms using Blast2GO. GO categories are as follow: biological process (BP), molecular function (MF), and cellular component (CC). The number of genes corresponding to each functional category is shown.

Additional file 5: Table S2. Assembly statistics and sequence mapping (XLSX $12 \mathrm{~kb}$ )

Additional file 6: Table S3. DEGs at 2 and 10 dpi obtained with severa methods, including DESeq, DESeq2, NOISeq and EdgeR.

Additional file 7: Table S4. Functional annotation of DEGs at 2 and 10 dpi obtained with the EdgeR method.

Additional file 8: Table S5. GO terms enrichment analysis, performed with the PANTHER classification system software (v.14.0). Gene Ontology categories significantly enriched in DEGs at $2 \mathrm{dpi}$, present in transcripts up regulated, in the infection caused by Fusarium in vanilla. In the table the Gene Ontology $(\mathrm{GO})$ terms that are significantly $(q \leq 0.05)$

overrepresented using are observed. 
Additional file 9: Table S6. GO terms enrichment analysis, performed with the PANTHER classification system software (v.14.0). Gene Ontology categories significantly enriched in DEGs at 2 dpi, present in transcripts down regulated, in the infection caused by Fusarium in vanilla. In the table the Gene Ontology $(\mathrm{GO})$ terms that are significantly $(q \leq 0.05)$ overrepresented using are observed.

Additional file 10: Figure S4. Schematic representation of biological processes enriched in DEGs at $2 \mathrm{dpi}$. a Biological processes enriched among up-regulated genes. $b$ Biological processes enriched among down-regulated genes. Enrichment analysis was performed with agriGO. Enriched GO terms considered as significant are indicated by corresponding color levels.

Additional file 11: Figure S5. Functional association networks among DEGs at $10 \mathrm{dpi}$. a Interactions among the up-regulated genes. b Interactions among the down-regulated genes. Colored lines between nodes indicate the various types of interaction: black line, co-expression; light blue line, association in curated databases; purple line, experimental.

Additional file 12: Table S7. In this table, the genes corresponding to the nodes of the network of genetic interactions, obtained with the string software, are observed. This analysis corresponds to the genes differentially expressed at $2 \mathrm{dpi}$, in the infection caused by Fusarium in vanilla. Genes (nodes) composing the central networks shown in Fig. 5.

\section{Abbreviations}

eiFs: Eukaryotic initiation factors; GCN: General control non-derepressible: $\log F C$ : $\log 2$ of fold change; RNA-Seq: High-throughput sequencing of RNA; RPL: Large subunit of ribosomal protein; RPS: Small subunit of ribosomal protein

\section{Acknowledgements}

MTSC gratefully acknowledges to the Consejo Nacional de Ciencia y Tecnología (CONACYT) for the scholarship provided (259580) and to the Tecnológico Nacional de México for financial support of this work. Also, thanks to the Biologist Lolvin Delaurens-Santacruz for his help during the experiments, as well as Dr. Alejandro Blanco, Dr. Gastón Contreras Jiménez and Dr. Matías Baranzelli for their valuable help, generous support and encouragement during the preparation this manuscript. Finally, we appreciate the technical assistance during RNA extractions to Edder Darío Aguilar-Méndez, Daniel Abisaí Jerez-Prieto, Dulce Natali Gómez-Hernández and Cecilio Mauricio-Ramos.

\section{Authors' contributions}

MTSC, JAG, LGIA and MLR conceived and designed the experiments. MTSC and EEEH performed the experiments and collected samples. VJJ, LVA, MTSC, EEEH and JGJ performed primary data analysis and carried out bioinformatics analysis. MTSC, JGJ and MLR conceived and organized the manuscript structure. All authors contributed during the manuscript preparation and approved the final manuscript.

\section{Funding}

This work was funded by Tecnológico Nacional de México (project number 5911.16-P Transcriptome of Vanilla planifolia Jacks., exposed to infection caused by Fusarium oxysporum f. sp. vanillae). The funders had no role in study design, data collection and analysis, decision to publish, or preparation of the manuscript.

\section{Availability of data and materials}

The datasets used and/or analyzed during the current study are available from the corresponding author on reasonable request and they were submitted to the GEO platform of NCBI-GenBank (Accession number: GSE134155).

\section{Ethics approval and consent to participate}

Not applicable.

\section{Consent for publication}

Not applicable.

\section{Competing interests}

The authors declare that they have no competing interests.

\section{Author details}

'Instituto de Biotecnología y Ecología Aplicada (INBIOTECA), Universidad Veracruzana, Avenida de las Culturas Veracruzanas s/n, Xalapa, Veracruz, Mexico. ${ }^{2}$ Instituto de Ecología, Universidad Nacional Autónoma de México, Circuito Exterior S/N anexo, Jardín Botánico exterior, Ciudad Universitaria, Ciudad de México, Mexico. ${ }^{3}$ Tecnológico Nacional de México, Instituto Tecnológico de Úrsulo Galván, Úrsulo Galván, Veracruz, Mexico. ${ }^{4}$ Consejo Nacional de Ciencia y Tecnología - Centro de Investigación en Biotecnología Aplicada, Instituto Politécnico Nacional (CIBA-IPN), Av. Insurgentes Sur 1582, Col. Crédito Constructor, Del. Benito Juárez, 03940 Ciudad de México, Mexico. ${ }^{5}$ Unidad Universitaria de Secuenciación Masiva y Bioinformática, Instituto de Biotecnología, Universidad Nacional Autónoma de México, Cuernavaca, Morelos, Mexico. Instituto de Ciencias Aplicadas y Tecnología, Universidad Nacional Autónoma de México, Ciudad de México, Mexico. 7Unidad de Genómica Avanzada, Langebio, Cinvestav, Km 9.6 Libramiento Norte Carretera León, Irapuato, Guanajuato, Mexico. ${ }^{8}$ Laboratorio de Genética e Interacciones Planta Microorganismos, Facultad de Ciencias Agrícolas, Universidad Veracruzana. Circuito Gonzalo Aguirre Beltrán s/n, Zona Universitaria, Xalapa, Veracruz, Mexico.

Received: 12 July 2019 Accepted: 28 October 2019 Published online: 08 November 2019

References

1. Bani M, Pérez-De-Luque A, Rubiales D, Rispail N. Physical and chemical barriers in root tissues contribute to quantitative resistance to Fusarium oxysporum f. sp. pisi in pea. Front Plant Sci. 2018;9(2):1-16. https://doi.org/10. 3389/fpls.2018.00199.

2. Shiu SH, Karlowski WM, Pan R, Tzeng YH, Mayer KF, et al. Comparative analysis of the receptor-like kinase family in Arabidopsis and rice. The Plant Cell. 2004;16:1220-34. https://doi.org/10.1105/tpc.020834.

3. Zhang J, Zhou JM. Plant immunity triggered by microbial molecular signatures. Mol Plant. 2010;3:783-93. https://doi.org/10.1093/mp/ssq035.

4. Bigeard J, Rayapuram N, Pflieger D, Hirt H. Phosphorylation-dependent regulation of plant chromatin and chromatin-associated proteins. Proteomics. 2014;14:2127-40. https://doi.org/10.1002/pmic.201400073.

5. Ausubel FM. Are innate immune signaling pathways in plants and animals conserved? Nat Immunol. 2005:973-9. https://doi.org/10.1038/ni1253.

6. Boller T, Felix G. A renaissance of elicitors: perception of microbe-associated molecular patterns and danger signals by pattern-recognition receptors. Annu Rev Plant Biol. 2009;60:379-406. https://doi.org/10.1146/annurev. arplant.57.032905.105346.

7. Yamaguchi Y, Huffaker A, Bryan AC, Tax FE, Ryan CA. PEPR2 is a second receptor for the Pep1 and Pep2 peptides and contributes to defense responses in Arabidopsis. Plant Cell. 2010:508-22. https://doi.org/10.1105/ tpc.109.068874

8. Macho AP, Zipfel C. Targeting of plant pattern recognition receptor triggered immunity by bacterial type III secretion system effectors. Curr Opin Microbiol. 2015;23:14-22. https://doi.org/10.1016/j.mib.2014.10.009

9. Guo M, Tian F, Wamboldt Y, Alfano JR. The majority of the type III effector inventory of Pseudomonas syringae pv. Tomato DC3000 can suppress plant immunity. Mol Plant-Microbe Interact. 2009;22:1069-80. https://doi.org/10. 1094/MPMI-22-9-1069

10. Zipfel C. Plant pattern-recognition receptors. Trends Immunol. 2014;35:34551. https://doi.org/10.1016/j.it.2014.05.004.

11. Jones JD, Dangl JL. The plant immune system. Nature. 2006:444:323-9. https://doi.org/10.1038/nature05286.

12. Chen $X$, Ronald PC. Innate immunity in rice. Trends Plant Sci. 2011:451-9. https://doi.org/10.1016/j.tplants.2011.04.003.

13. Whitmarsh AJ. Regulation of gene transcription by mitogen-activated protein kinase signaling pathways. Biochim Biophys Acta - Mol Cell Res. 2007;1773(8):1285-98. https://doi.org/10.1016/j.bbamcr.2006.11.011.

14. Chiang YH, Coaker G. Effector triggered immunity: NLR immune perception and downstream defense responses. Arabidopsis Book. 2015;13:e0183. https://doi.org/10.1199/tab.0183.

15. Spoel SH, Dong X. How do plants achieve immunity? Defense without specialized immune cells. Nat Rev Immunol. 2012;12(2):89-100. https://doi. org/10.1038/nri3141 
16. Naito K, Ishiga Y, Toyoda K, Shiraishi T, Ichinose Y. N-terminal domain including conserved flg22 is required for flagellin-induced hypersensitive cell death in Arabidopsis thaliana. J Gen Plant Pathol. 2007;73:281-5. https:// doi.org/10.1007/s10327-007-0017-9.

17. Clough SJ, Fengler KA, Yu IC, Lippok B, Smith RK, Bent AF. The Arabidopsis dnd1 "defense, no death" gene encodes a mutated cyclic nucleotide-gated ion channel. Proc Natl Acad Sci U S A. 2000;97:9323-8. https://doi.org/10. 1073/pnas.150005697.

18. Coll NS, Epple P, Dangl JL. Programmed cell death in the plant immune system. Cell Death Differ. 2011;18:1247-56. https://doi.org/10.1038/cdd.2011.37.

19. Anilkumar A. Vanilla cultivation, a profitable Agri-based enterprise. Kerala Calling. 2004;11:26-30.

20. Hernández-Hernández J. Vanilla Diseases. In: Handbook of Vanilla science and technology. London: Wiley-Blackwell Publishing; 2011. p. 27-39. https:// doi.org/10.1002/9781119377320.

21. De La Cruz MJ, Rodriguez Jiménes GC, García HS. VANILLA postharvest operations. INPhO Post-harvest Compendium. Food and Agriculture Organization (FAO); 2009. http://www.fao.org/fileadmin/user_upload/inpho/ docs/Post_Harvest_Compendium_-_Vanilla.pdf.

22. Kalimuthu K, SenThilkumar R, Vilayakumar S. In vitro micropropagation of orchid, Oncidium sp. (dancing dolls). Afr J Biotechnol. 2007:6(10):1171-4. https://doi.org/10.4314/ajb.v6i10.57136.

23. Roling W, Kerler J. Microorganisms with a taste for vanilla:microbial ecology of traditional indonesian vanilla curing. Appl Environ Microbiol. 2001;5(67): 1995-2002. https://doi.org/10.1128/AEM.67.5.1995-2003.2001.

24. Pinaria A, Burgess L. Fusarium species associated with vanilla stem rot in Indonesia. Austr Plant Pathol. 2010; 39: 83-176. doi: https://doi.org/10.1071/ AP09079.

25. Ramírez-Mosqueda M, Iglesias-Andreu L, Noa-Carrazana J, Armas-Silva A. Selection of Vanilla planifolia Jacks. ex Andrews genotypes resistant to Fusarium oxysporum f. sp. vanillae, by biotechnology. Agroproductividad. 2018;11:70-4.

26. Dignum MJW, Kerler J, Verpoorte R. $\beta$-Glucosidase and peroxidase stability in crude enzyme extracts from green beans of Vanilla planifolia Andrews. Phytochem Anal. 2001;12:174-9. https://doi.org/10.1002/pca.578.

27. Bhai S, Dhanesh J. Occurrence of fungal diseases in vanilla (Vanilla planifolia Andrews) in Kerala. J Spices Aromatic Crops. 2008;17:140-8.

28. Fravel D, Olivain C, Alabouvette C. Fusarium oxysporum and its biocontrol. New Phytologist. 2003; 157: 493-502. doi: https://doi.org/10.1046/j.14698137.2003.00700.x

29. Bory S, Lubinsky P, Risterucci AM, Noyer JL, Grisoni M, Duval MF, Besse P. Patterns of introduction and diversification of Vanilla planifolia (Orchidaceae) in Réunion Island (Indian Ocean). Am J Bot. 2008;95:805-15. https://doi.org/10.3732/ajb.2007332

30. Lubinsky P, Bory S, Hernández JH, Kim SC, Gómez-Pompa A. Origins and dispersal of cultivated Vanilla (Vanilla planifolia Jacks. [Orchidaceae]). Econ Botany. 2008;62:127-38. https://doi.org/10.1007/s12231-008-9014-y.

31. Bai TT, Xie WB, Zhou PP, et al. Transcriptome and Expression Profile Analysis of Highly Resistant and Susceptible Banana Roots Challenged with Fusarium oxysporum f. sp. cubense Tropical Race 4. PLoS ONE. 2013;8(9):e73945. https://doi.org/10.1371/journal.pone.0073945.

32. Li CY, Deng GM, Yang J, Viljoen A, Jin Y, Kuang RB, Zuo CW, Lv ZC, Yang QS, Sheng $\mathrm{O}$, Wei YR, Hu CH, Dong T, Yi GJ. Transcriptome profiling of resistant and susceptible Cavendish banana roots following inoculation with Fusarium oxysporum f. sp. cubense tropical race 4. BMC Genomics. 2012;13: 374. https://doi.org/10.1186/1471-2164-13-374.

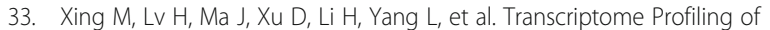
Resistance to Fusarium oxysporum f. sp. conglutinans in Cabbage (Brassica oleracea) Roots. PLoS ONE. 2016;11(2):e0148048. https://doi.org/10.1371/ journal.pone.0148048.

34. Smith-Unna R, Boursnell C, Patro R, Hibberd JM, Kelly S. TransRate:reference free quality assessment of de novo transcriptome assemblies. Genome Res. 2016;26:1134-44. https://doi.org/10.1101/gr.196469.115.

35. Langmead B, Salzberg SL. Fast Gapped-Read Alignment with Bowtie 2. Nat Methods. 2012;9:357-9. https://doi.org/10.1038/nmeth.1923.

36. Gôtz S, Garcia-Gomez JM, Terol J, Williams TD, Nagaraj SH, Nueda MJ, Robles M, Talon M, Dopazo J, Conesa A. High-throughput functional annotation and data mining with the blast2go suite. Nucl Acids Res. 2018. https://doi.org/10.1093/nar/gkn176.

37. Thimm $O$, Bläsing $O$, Gibon $Y$, Nagel $A$, Meyer $S$, Krüger $P$, et al. MAPMAN: a user-driven tool to display genomics data sets onto diagrams of metabolic pathways and other biological processes. Plant J. 2004;37(6):914-39. https:// doi.org/10.1111/j.1365-313x.2004.02016.x.

38. Szklarczyk D, Morris JH, Cook H, Kuhn M, Wyder S, Simonovic M, et al. The STRING database in 2017: Quality-controlled protein-protein association networks, made broadly accessible. Nucleic Acids Res. 2017;45(D1):D362-8. https://doi.org/10.1038/s41598-019-45072-8.

39. Vijayan K, Srivastava PP, Raju PJ, Saratchandra B. Breeding for higher productivity in mulberry. Czech J. Genet. Plant Breed. 2012;48:147-56. https://doi.org/10.17221/162/2011-CJGPB.

40. Ramírez-Mosqueda MA, Iglesias-Andreu LG, Teixeira da Silva JA, et al. In vitro selection of vanilla plants resistant to Fusarium oxysporum f. sp. vanillae. Acta Physiol Plant. 2019;41:40. https://doi.org/10.1007/s11738-019-2832-y.

41. Houston K, Tucker MR, Chowdhury J, Shirley N, Little A. The plant cell wall: a complex and dynamic structure as revealed by the responses of genes under stress conditions. Front Plant Sci. 2016;7:984. https://doi.org/10.3389/ fpls.2016.00984.

42. Merchante C, Stepanova AN, Alonso JM. Translation regulation in plants: an interesting past, an exciting present and a promising future. Plant J. 2017; 90(4):628-53. https://doi.org/10.1111/tpj.13520.

43. Gonskikh Y, Polacek N. Alterations of the translation apparatus during aging and stress response. Mech Ageing Dev. 2017;168:30-6. https://doi.org/10. 1016/j.mad.2017.04.003.

44. Warner JR, Mclntosh KB. How common are extraribosomal functions of ribosomal proteins? Mol Cell. 2009;34:3-11. https://doi.org/10.1016/j.molcel. 2009.03.006.

45. Barakat A, Szick-Miranda K, Chang IF, Guyot R, Blanc G, Cooke R, et al. The organization of cytoplasmic ribosomal protein genes in the Arabidopsis genome. Plant Physiol. 2001;127:398-415. https://doi.org/10.1104/pp.010265.

46. Perry RP. Balanced production of ribosomal proteins. Gene. 2007:401:1-3.

47. Yang L, Xie C, Li W, Ruijie Z, Dengwei J, Qing Y. Expression of a wild eggplant ribosomal protein $L 13 a$ in potato enhances resistance to Verticillium dahliae. Plant Cell Tissue Organ Cult. 2013;115:329-40. https:// doi.org/10.1007/s11240-013-0365-4.

48. Falcone Ferreyra ML, Rius S, Emiliani J, Pourcel L, Feller A, Morohashi K, Casati P, Grotewold E. Cloning and characterization of a UV-B inducible maize flavonol synthase. Plant J. 2010;62:77-91. https://doi.org/10.1111/j. 1365-313X.2010.04133.x.

49. Nagaraj S, Senthil-Kumar M, Ramu VS, Wang K, Mysore KS. Plant Ribosomal Proteins, RPL12 and RPL19, Play a Role in Nonhost Disease Resistance against Bacterial Pathogens. Front. Plant Sci. 2016;6:1192. https://doi.org/10. 3389/fpls.2015.01192.

50. Yang C, Zhang C, Dittman JD, Whitham SA. Differential requirement of ribosomal protein $\mathrm{S} 6$ by plant RNA viruses with different translation initiation strategies. Virology. 2009;390:163-73. https://doi.org/10.1016/j.virol. 2009.05.018

51. Zhang J, Xia C, Duan C, Sun S, Wang X, Wu X, Zhu Z. Identification and candidate gene analysis of a novel Phytophthora resistance gene Rps10 in a Chinese soybean cultivar. PLoS One. 2013;8(7):e69799. https://doi.org/10. 1371/journal.pone.0069799.

52. Saha A, Das S, Moin M, Dutta M, Bakshi A, Madhav M, Kirti P. Genome-wide identification and comprehensive expression profiling of ribosomal protein small subunit genes and their comparative analysis with the large subunit genes in rice. Front Plant Sci. 2017;8:1553. https://doi.org/10.3389/fpls.2017.01553.

53. Hulm JL, McIntosh KB, Bonham-Smith PC. Variation in transcript abundance among the four members of the Arabidopsis thaliana RIBOSOMAL PROTEIN S15a gene family. Plant Sci. 2005;169:267-78. https://doi.org/10.1016/j. plantsci.2005.04.001.

54. Cherepneva GN, Schmidt KH, Kulaeva ON, Oelmüller R, Kusnetsov V. Expression of the ribosomal proteins S14 S16 L13a and L30 is regulated by cytokinin and abscisic acid: implication of the involvement of phytohormones in translational processes. Plant Sci. 2003;165:925-32. https://doi.org/10.1016/S0168-9452(03)00204-8.

55. Casati P, Virginia W. Gene expression profiling in response to ultraviolet radiation in maize genotypes with varying flavonoid content. Plant Physiol. 2003;132:1739-54. https://doi.org/10.1104/pp.103.022871.

56. Ferreyra MLF, Casadevall R, Luciani MD, Pezza A, Casati P. New evidence for differential roles of 110 ribosomal proteins from Arabidopsis. Plant Physiol. 2013;163:378-91. https://doi.org/10.1104/pp.113.223222.

57. Kim KY, Park SW, Chung YS, Chung CH, Kim Jl, Lee JH. Molecular cloning of low-temperature-inducible ribosomal proteins from soybean. J Exp Bot. 2004;55:1153-5. https://doi.org/10.1093/jxb/erh125. 
58. Sáez-Vásquez J, Gallois P, Delseny M. Accumulation and nuclear targeting of BnC24 a Brassica napus ribosomal protein corresponding to a mRNA accumulating in response to cold treatment. Plant Sci. 2000;156:35-46. https://doi.org/10.1016/S0168-9452(00)00229-6.

59. Imai A, Komura M, Kawano E, Kuwashiro Y, Takahashi T. A semi-dominant mutation in the ribosomal protein L10 gene suppresses the dwarf phenotype of the acl5 mutant in Arabidopsis thaliana. Plant J. 2008;56:88190. https://doi.org/10.1111/j.1365-313X.2008.03647.x.

60. Ito T, Gyung-Tae K, Kazuo S. Disruption of an Arabidopsis cytoplasmic ribosomal protein $\mathrm{S} 13$-homologous gene by transposon-mediated mutagenesis causes aberrant growth and development. Plant J. 2000;22: 257-64. https://doi.org/10.1046/j.1365-313x.2000.00728.x.

61. Degenhardt RF, Bonham-Smith PC. Arabidopsis ribosomal proteins RPL23aA and RPL23aB are differentially targeted to the nucleolus and are disparately required for normal development. Plant Physiol. 2008;147:128-42. https:// doi.org/10.1104/pp.107.111799.

62. Muench DG, Zhang C, Dahodwala M. Control of cytoplasmic translation in plants. Wiley Interdiscip Rev RNA. 2012;3:178-94. https://doi.org/10.1002/ wrna.1104.

63. Browning KS, Bailey SJ. Mechanism of cytoplasmic mRNA translation. Arabidopsis Book. 2015;13:e0176. https://doi.org/10.1199/tab. 0176.

64. Nishimura EK, Granter SR, Fisher DE. Mechanisms of hair graying: incomplete melanocyte stem cell maintenance in the niche. Science. 2005; 307:720-4. https://doi.org/10.1126/science.1099593.

65. Revenkova E, Masson J, Koncz C, Afsar K, Jakovleva L, Paszkowski J. Involvement of Arabidopsis thaliana ribosomal protein S27 in mRNA degradation triggered by genotoxic stress. EMBO J. 1999;18:490-9. https:// doi.org/10.1093/emboj/18.2.490.

66. Szakonyi D, Byrne ME. Ribosomal protein L27a is required for growth and patterning in Arabidopsis thaliana. Plant J. 2011;65:269-81. https://doi.org/ 10.1111/j.1365-313X.2010.04422.x.

67. Horiguchi G, Van Lijsebettens M, Candela H, Micol JL, Tsukaya H. Ribosomes and translation in plant developmental control. Plant Sci. 2012;191-192:2434. https://doi.org/10.1016/j.plantsci.2012.04.008.

68. Boex-Fontvieille E, Daventure M, Jossier M, Zivy M, Hodges M, Tcherkez G. Photosynthetic control of Arabidopsis leaf cytoplasmic translation initiation by protein phosphorylation. PLoS One. 2013;8:e70692. https://doi.org/10. 1371/journal.pone.0070692.

69. Zhang Y, Wang Y, Kanyuka K, Parry MAJ, Powers SJ, Halford NG. GCN2dependent phosphorylation of eukaryotic translation initiation factor-2alpha in Arabidopsis. J Exp Bot. 2008;59:3131-41. https://doi.org/10.1093/jxb/ern169.

70. Liu X, Merchant A, Rockett KS, McCormack M, Pajerowska-Mukhtar KM. Characterization of Arabidopsis thaliana GCN2 kinase roles in seed germination and plant development. Plant Signal Behav. 2015;10:e992264. https://doi.org/10.4161/15592324.2014.992264.

71. Hannig EM, et al. The translational activator GCN3 functions downstream from GCN1 and GCN2 in the regulatory pathway that couples GCN4 expression to amino acid availability in Saccharomyces cerevisiae. Genetics. 1990;126(3):549-62.

72. Sormani R, Masclaux-Daubresse C, Daniele-Vedele F, Chardon F. Transcriptional regulation of ribosome components are determined by stress according to cellular compartments in Arabidopsis thaliana. PLoS One. 2011;6:e28070. https://doi.org/10.1371/journal.pone.0028070.

73. Wang L, Li H, Zhao C, et al. The inhibition of protein translation mediated by AtGCN1 is essential for cold tolerance in Arabidopsis thaliana. Plant Cell Environ. 2017:40:56-68. https://doi.org/10.1111/pce.12826.

74. Sesma A, Castresana C, Castellano MM. Regulation of translation by TOR, elF4E and elF2a in plants: current knowledge, challenges and future perspectives. Front Plant Sci. 2017;8:1-7. https://doi.org/10.3389/ fpls.2017.00644.

75. Wang J, Lan P, Gao H, Zheng L, Li W, Schmidt W. Expression changes of ribosomal proteins in phosphate-and iron-deficient Arabidopsis roots predict stress-specific alterations in ribosome composition. BMC Genomics. 2013;14:783. https://doi.org/10.1186/1471-2164-14-783.

76. Bory S, Catrice O, Brown SC, Leitch IJ, Gigant R, Chiroleu F, Grisoni M, Duval M-F, Besse P. Natural polyploidy in Vanilla planifolia (Orchidaceae). Genome. Vol. 2008;51:816-26. https://doi.org/10.1139/G08-068.

77. Adame-García J, Rodríguez-Guerra R, Iglesias-Andreu LG, Ramos-Prado JM, Luna-Rodríguez M. Molecular identification and pathogenic variation of Fusarium species isolated from Vanilla planifolia in Papantla, Mexico. Bot. Sci. 2015;93:669-78. https://doi.org/10.17129/botsci.142.
78. Flores-de la Rosa FR, De Luna E, Adame-García J, Iglesias-Andreu LG, LunaRodríguez M. Phylogenetic position and nucleotide diversity of Fusarium oxysporum f. sp. vanillae worldwide based on translation elongation factor $1 \mathrm{a}$ sequences. Plant Pathol. 2018;67(6):1278-85. https:/doi.org/10.1111/ppa.12847.

79. Koyyappurath S, Atuahiva T, Le Guen R, Batina H, Le Squin S, Gautheron N, et al. Fusarium oxysporum f. sp. radicis-vanillae is the causal agent of root and stem rot of Vanilla. Plant Pathol. 2015. https://doi.org/10.1111/ppa.12445.

80. Valderrama-Cháirez ML, Cruz-Hernández A, Paredes-López O. Isolation of functional RNA from cactus fruit. Plant Mol. Biol. Rep. 2002;20:279-86. https://doi.org/10.1007/BF02782463.

81. Simão FA, Waterhouse RM, loannidis P, Kriventseva EV, Zdobnov EM. BUSCO: assessing genome assembly and annotation completeness with single-copy orthologs. Bioinformatics. 2015;31:3210. https://doi.org/10.1093/ bioinformatics/btv351.

82. Jiménez-Jacinto V, Sanchez-Flores A, Vega-Alvarado L. Integrative differential expression analysis for multiple EXperiments (IDEAMEX): a web server tool for integrated RNA-Seq data analysis. Front Genet. 2019;10(279):1-16. https://doi.org/10.3389/fgene.2019.00279.

83. Anders $\mathrm{S}$, Huber W. Differential expression analysis for sequence count data. Genome Biol. 2010;11:106. https://doi.org/10.1186/gb-2010-11-10-r106.

84. Love MI, Anders S, Huber W. Moderated estimation of fold change and dispersion for Rna-Seq data with Deseq2. Genome Biol. 2014;15(550):1-21. https://doi.org/10.1186/s13059-014-0550-8.

85. Tarazona S, Turra D, Furio-Tari P. Data quality aware analysis of differential expression in Rna-Seq with Noiseq R/bioc package. Nucleic Acids Res. 2015; 43(21):e140. https://doi.org/10.1093/nar/gkv711.

86. Robinson MD, Smyth GK, McCarthy DJ. EdgeR: a bioconductor package for differential expression analysis of digital gene expression data. Bioinformatics. 2010;26(1):139-40. https:/doi.org/10.1093/bioinformatics/btp616.

87. Wickham H. A layered grammar of graphics. J Comput Graph Stat. 2009. https://doi.org/10.1198/jcgs.2009.07098.

88. Tian T, Liu Y, Yan H, You Q, Yi X, Du Z, Xu W, Su Z. agriGO v2.0: a GO analysis toolkit for the agricultural community. 2017; update. Nucleic Acids Res. 2017:gkx382. https://doi.org/10.1093/nar/gkx382.

\section{Publisher's Note}

Springer Nature remains neutral with regard to jurisdictional claims in published maps and institutional affiliations.

Ready to submit your research? Choose BMC and benefit from

- fast, convenient online submission

- thorough peer review by experienced researchers in your field

- rapid publication on acceptance

- support for research data, including large and complex data types

- gold Open Access which fosters wider collaboration and increased citations

- maximum visibility for your research: over $100 \mathrm{M}$ website views per year

At BMC, research is always in progress.

Learn more biomedcentral.com/submissions 